\title{
A Study of Physiology of Rice Varieties with Intermittent Irrigation and Conventional Method on System of Rice Intensification
}

\author{
Bambang Heri Isnawan \\ Department of Agrotechnonogy Faculty \\ of Agriculture \\ Universitas Muhammadiyah Yogyakarta \\ Yogyakarta, Indonesia \\ bambang_hi@yahoo.com
}

\author{
Susila \\ Department of Agrotechnonogy Faculty \\ of Agriculture \\ Universitas Muhammadiyah Yogyakarta \\ Yogyakarta, Indonesia
}

\author{
Mulyono \\ Department of Agrotechnonogy Faculty \\ of Agriculture \\ Universitas Muhammadiyah Yogyakarta \\ Yogyakarta, Indonesia
}

\begin{abstract}
Rice production could be increased by System of Rice Intensifications, that is water-saving, fertilizer-saving, and production cost-saving. Using quality varieties could increase the production of rice. This research analyzed the physiological growth and yield on varieties of rice plants, with intermittent irrigation on SRI. This research was conducted in the Faculty of Agriculture, Universitas Muhammadiyah Yogyakarta from July to November 2017. This research was arranged in a $5 \times 2$ factorial design in Completely Randomized Design with three replications. The first factor consisted of five rice varieties i.e. IR-64, Mekongga, Inpari Sidenuk, Ciherang, and HIPA-18. The second factor was irrigation, consisting of two levels, i.e. SRI and conventional methods. The results of this research showed that the Harvest Index of IR-64 was higher than those of Ciherang and HIPA-18. Inpari Sidenuk variety had the lowest Harvest Index. The grain weight and unfilled grain weight of Ciherang, HIPA-18 and Mekongga were better than those of Inpari Sidenuk. SRI irrigation affected the fresh weight and root length of rice plants. SRI irrigation conditions produced heavier fresh weight and longer root than conventional irrigation. SRI irrigation conditions produced heavier fresh weight and longer root than conventional irrigation. Productive tillers of IR 64 variety with irrigation treatment using SRI was higher than Mekongga and Inpari Sidenuk using SRI, and Inpari Sidenuk using conventional irrigation method.
\end{abstract}

Keywords: Intermittent Irrigation, Physiology of Rice Varieties, System of Rice Intensification

\section{INTRODUCTION}

In Indonesia, rice plays an important role not only as a staple food source, but as the main source of income for most rural communities. Lack of production may influence various aspects of life, including social, economic, even political aspects. The population of Indonesia in 2014 was approximately 252,165 million people, requiring about 53.6 million tons of grain per year or equivalent to 33.5 million tons of rice. The national rice stocks in 2012/2013 declined from 7.4 to 6.48 million metric tons in 2013/2014, meaning that there was a $26 \%$ decrease within two years [1]. Thus, it is necessary for the government to intensively increase rice productivity and production in order to stabilize the price of rice.

One of the causes of the low rice production in Indonesia is in general because farmers cultivate rice plants not as recommended, for examples inappropriate tillage and fertilizer dose as well as still use of conventional system. In conventional method, seedlings are generally tranplanted at the age of 20-30 days with 5-7 seedlings or even more per hole. Delaying the transplantation of seedlings may cause the seedlings to have produced tillers, so lifting the seedlings may distrub the lifted growth of the tillers. In addition, planting too many seedlings in a hole may cause these seedlings to compete to absorb nutrient, light and space so the growth of the tillers are not optimal [2].

In recent years, one of the innovations being developed in rice farming is SRI (System of Rice Intensification). According to [3]. SRI could increase rice production to $78 \%$, save water to $40 \%$,save fertilizer to $50 \%$, and save production cost to $20 \%$. Further, [4] explained that SRI also results in better quality of rice than conventional method. Cultivating using SRI also results in more tillers, thicker root development, and more grains per panicle. Rice farming using SRI method is emphasized on some crucial aspects, among others, transplantation of seedlings aged 8-fifteen days, planting spacing of $25 \mathrm{~cm} \times 25 \mathrm{~cm}$, not continuously flooded, one seed per hole and periodical watering [5].

The use of superior varieties in an area also largely serves as a success factor to increase the production of rice. Varieties will be tested using superior varieties, divided into two groups i.e. hybrids and inbred, i.e. IR 64, Ciherang, Mekongga, Inpari Sidenuk and HIPA 18. Rice varieties determine the rice production in each region. Similarly, environmental factors also affect the growth and development of plants, e.g. temperature, soil structure, soil type, and soil $\mathrm{pH}$. Superior and local varieties have different adaptation abilities to different cropping patterns; therefore, it is necessary to test both superior and local varieties using SRI method by performing intermittent irrigation and continuous flow. This aims to find out whether, in terms of the environmental aspects, these varieties can grow and generate optimal production.

The conventional system of rice cultivation uses muchwater because rice fields are continuously flooded, reducing the oxygen content in the soil. This leads to nonoptimal process of photosynthesis that the photosynthesis system rice only contributes to $50 \%$ increase compared to the 
expected [6]. Besides, this also disturbs root development, reduces the number of total and productive tillers, as well as slows down the harvest time. This research aimed at knowing the influence of SRI and conventional methods of irrigation to the physiology, growth and yields in some rice varieties.

\section{METHODS}

This research used experimental method with a $5 \times 2$ factorial Completely Randomized Design (CRD). The first factor was varieties (V) consisting of five levels i.e. IR 64, Mekongga, Ciherang, Inpari Sidenuk, HIPA 18, and the second factor was irrigation system (A) consisting of two levels, i.e. SRI and conventional methods with ten treatment combinations and three replications.

Each experimental unit was planted 6 plants/pots, with five sample plants. The research was conducted at the experimental farm of the Faculty of Agriculture University Muhammadiyah Yogyakarta. The research was carried out from July to November 2017.

The variables of the physiology, growth, and yield of rice plants consisted of: plant height $(\mathrm{cm})$, number of tillers, fresh weight (gram), dry weight (gram), root length $(\mathrm{cm})$, leaf area $(\mathrm{cm} 2)$ panicle length $(\mathrm{cm})$, harvest index $(\mathrm{g})$, CGR (g/m2/week), NAR (g/dm2/week), SLW (g/dm2), grain weight per plant (gram), and unfilled grain percentage $(\%)$.

The data were analyzed using Anova (Analysis of variance) at $\alpha=5 \%$. If there were significant differences among treattments, then Duncan Multiple Range Test (DMRT) at level $\alpha=5 \%$ was done.

\section{RESULTS AND DISCUSSION}

\section{A. Growth of Rice Plant}

Table 1 shows the average plant height, number of leaves, fresh weight and dry weight of the rice plants aged 12 weeks. The plant height showed that there was no significantl interaction between varieties and irrigation. The variety treatment showed real growth differences, whereas at the irrigation treatment showed there was no significant difference. The treatment on HIPA 18 variety showed a higher growth than Ciherang and Sidenuk Inpari varieties. The treatments on Sidenuk, Inpari, and Ciherang showed higher growth than that on Mekongga. The treatment on Mekongga variety showed higher growth than that of IR-64. The growth in any varieties in terms of plant height did not show the same growth, depending on the varieties. Hipa-18 had a height of \pm $103 \mathrm{~cm}$ and leaf erectness [7].

The results of rice varieties in Table 1 showed that there was no significant interaction between varieties and irrigation. The variety treatments showed no significant difference in the growth. Similarly, the irigation treatments also showed no significant difference. The number of tillers was 15-16 tillers per plant. This is in accordance with a statement [8] that, if compared with superior varieties, the new rice variety is different in terms of stronger rice straw, greener and thicker leaves, medium tillers, and denser and thicker panicle.

The results of the fresh weight of rice plants in Table 1 showed that there was no real interaction between varieties and irrigation. Both the variety and irrigation treatments showed significant difference in the growth. Inpari Sidenuk variety had higher fresh weight than Hipa18 and Mekongga i.e. 310.80 grams.

Table 1. Average of plant height, fresh weight and dry weight of rice plants aged 12 weeks

\begin{tabular}{lccc}
\hline Treatment & $\begin{array}{c}\text { Plant height } \\
(\mathbf{c m})\end{array}$ & $\begin{array}{c}\text { Fresh weight } \\
\text { (grams) }\end{array}$ & $\begin{array}{c}\text { Dry weight } \\
\text { (grams) }\end{array}$ \\
\hline IR-64 & $81.49 \mathrm{~s}$ & $87.94 \mathrm{r}$ & $35.93 \mathrm{q}$ \\
Mekongga & $89.02 \mathrm{r}$ & $244.33 \mathrm{q}$ & $54.76 \mathrm{p}$ \\
Ciherang & $97.06 \mathrm{q}$ & $274.41 \mathrm{pq}$ & $57.10 \mathrm{p}$ \\
Inpari sidenuk & $98.67 \mathrm{q}$ & $310.80 \mathrm{p}$ & $60.36 \mathrm{p}$ \\
HIPA 18 & $105.66 \mathrm{p}$ & $243.35 \mathrm{q}$ & $51.99 \mathrm{p}$ \\
\hline SRI & $93.83 \mathrm{a}$ & $262.26 \mathrm{a}$ & $53.78 \mathrm{a}$ \\
Conventional & $94.93 \mathrm{a}$ & $202.07 \mathrm{~b}$ & $50.31 \mathrm{a}$ \\
\hline Interaction & $(-)$ & $(-)$ & $(-)$ \\
\hline
\end{tabular}

Numbers followed by the same letter in a column show there is no significant difference based on the $\mathrm{F}$ test and DMRT at $\alpha$ level $=5 \% .(-)=$ There is no significant interaction

Mekongga and Hipa-18 had higher fresh weight than IR 64. In fact, plant growth depends on the interaction between cells and environment [9]. Irrigation using SRI method showed higher fresh weight than that using conventional method i.e. 262.26 grams. Intermittent irrigation which provides less amount of water makes rice plants absorb the water. This is in line with [10] that when there is too much water, the excess water becomes inefficient or not beneficial to the growth of plants.

Figure 1. (a) showed plant height at the variety treatment, where HIPA 18 variety had the highest plant height from week 2 to week 12. This is because HIPA 18 variety had erectness in growth, contributing to the plant height. Figure 3 (b) shows the irrigation treatment, where the plant height of HIPA-18 was higher in conventional method. Water shortage will disturb the growth of plant height due to limited amount of water absorbed during the rice growth. [11] stated that drought could affect growth, yield, and quality of plants.

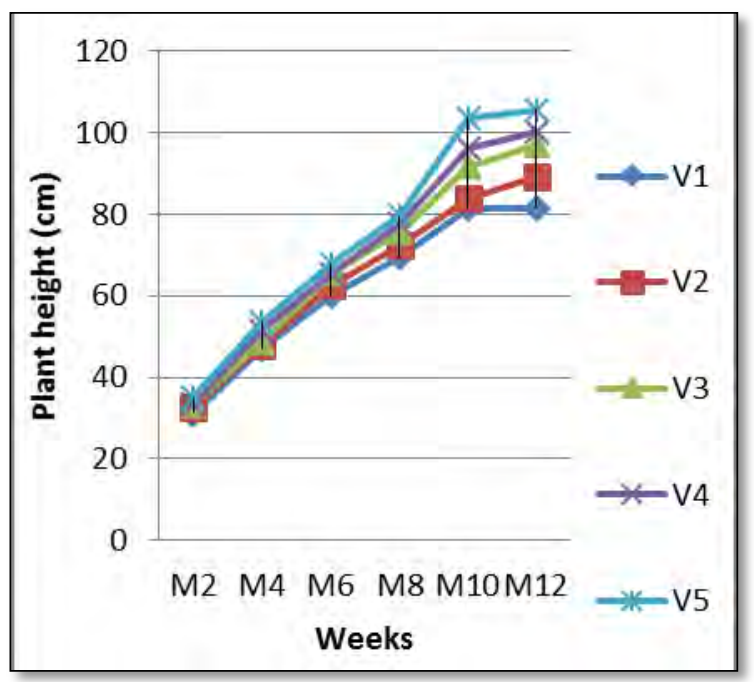

Figure 1 (a). Plant Height of Rice Plant 


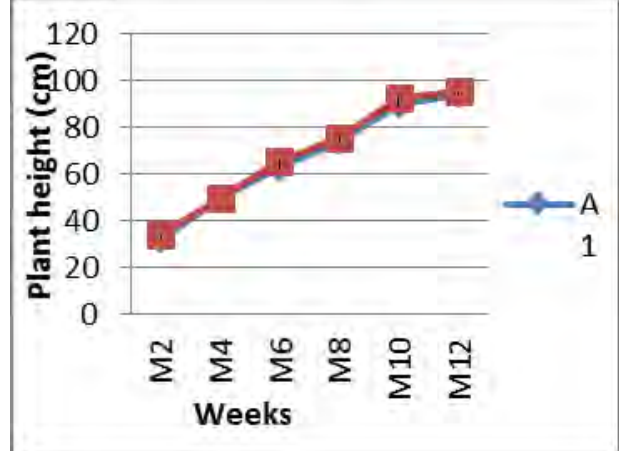

Figure 1 (b). Plant Height of Rice Plant

$$
\begin{array}{ll}
\text { V1 }=\text { IR-64 } & \text { V3 }=\text { Ciherang } \\
\text { V4 }=\text { Inpari Sidenuk } & \text { A1 }=\text { SRI } \\
\text { V2 }=\text { Mekongga } & \text { A2 }=\text { Conventional } \\
\text { V5 }=\text { HIPA 18 } &
\end{array}
$$

Figure 2 (a) shows the variety treatment by irrigation, where there was an increase in the fresh weight of rice plants from the $4^{\text {th }}, 8^{\text {th }}$, and $12^{\text {th }}$ week. In the $4^{\text {th }}$ week, Mekongga showed the highest growth in terms of fresh weight, while in the $8^{\text {th }}$ week, Ciherang showed the highest growth. Figure 5 (b) showed that the conventional irrigation in the $4^{\text {th }}$-week produced higher fresh weight than SRI, while on the $8^{\text {th }}$ and $12^{\text {th }}$ weeks, SRI generated higher fresh weight than conventional method. However, IR 64 variety had relatively equal growth in the $8^{\text {th }}$ and $12^{\text {th }}$ week because IR-64 variety has a relatively short life compared to other varieties. The life of IR-64 is 100 days [5].

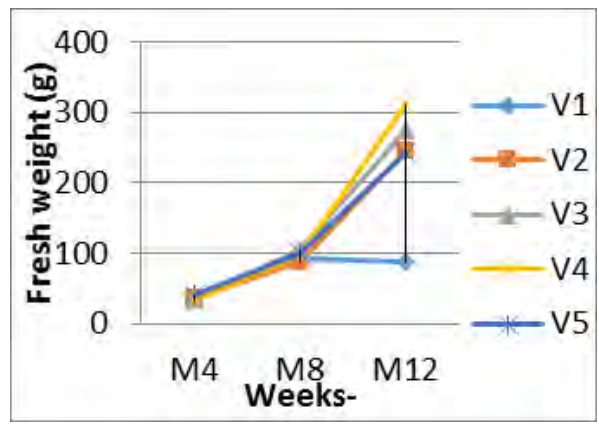

Figure 2 (a). Graphs of Fresh Weight of Rice Plants

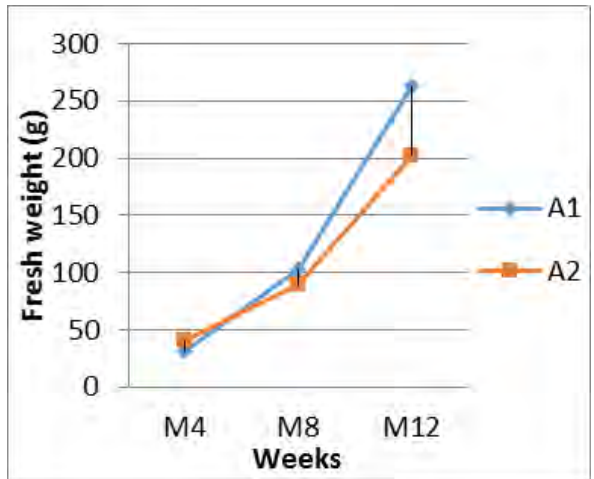

Figure 2 (b). Graphs of Fresh Weight of Rice Plants

$$
\begin{aligned}
\text { V1 } & =\text { IR } 64 & \text { V4 } & =\text { Inpari Sidenuk } \\
\text { V2 } & =\text { Mekongga } & \text { V5 } & =\text { HIPA } 18 \\
\text { V3 } & =\text { Ciherang } & \text { A1 } & =\text { SRI }
\end{aligned}
$$

\section{$\mathrm{A} 2=$ Conventional}

The results of the dry weight of rice plants in Table 1 showed that there was no significant interaction between varieties and irrigation. The variety treatment showed significantly different yield, whereas at the irrigation treatment showed no significant difference. Inpari Sidenuk, Ciherang, Mekongga, and HIPA-18 showed higher dry weight than IR-64. This shows that rice plants grow quite well during vegetative stage, evident from the same dry weights on some varieties except IR 64. The irrigation was done quite well for the dry weight of rice. Dry weight depends on the absorption of light, $\mathrm{CO} 2$ and water.

Figure 3 (a) shows that in week 4 of treatment, Mekongga showed the highest growth in terms of dry weight, in week 8, Ciherang showed the highest growth, while in week 12, Inpari Sidenuk showed the highest growth. Figure 3 (b) shows that SRI generated the highest dry weight on the $4^{\text {th }}, 8^{\text {th }}$ and $12^{\text {th }}$ week. This shows that intermittent irrigation is able to increase the rate of photosynthesis because intermitten irrigation will create aerobic condition, allowing oxygen to penetrate into the soil and affect the rate of photosynthesis.

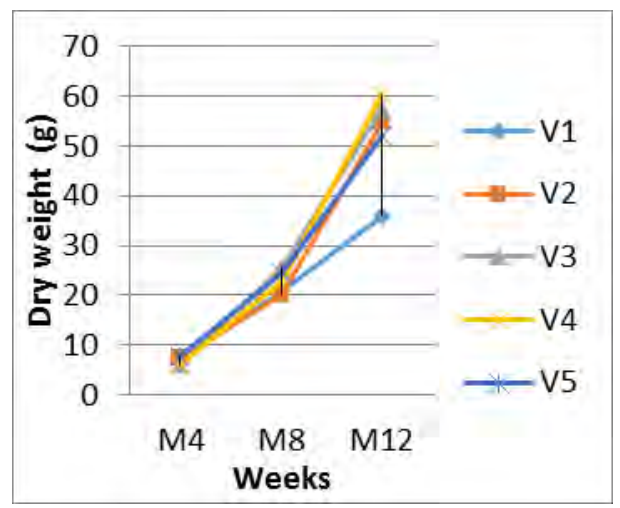

Figure 3 (a). Graphs of Dry Weight of Rice Plants

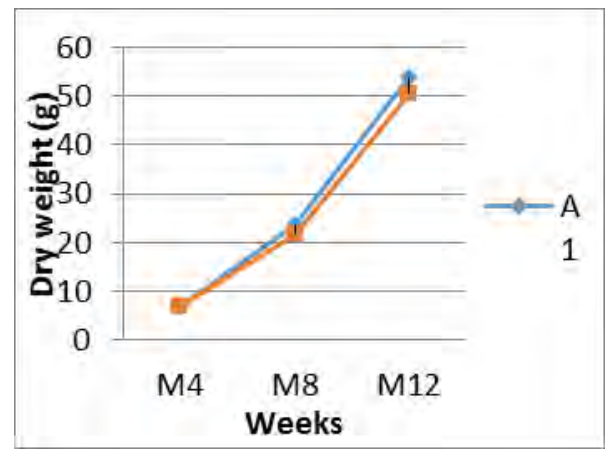

Figure 3 (b). Graphs of Dry Weight of Rice Plants

$$
\begin{array}{llrl}
\text { V1 } & =\text { IR-64 } & \text { V4 } & =\text { Inpari Sidenuk } \\
\text { V2 } & =\text { Mekongga } & \text { V5 } & =\text { HIPA } 18 \\
\text { V3 } & =\text { Ciherang } & \text { A1 } & =\text { SRI } \\
\text { A2 } & =\text { Conventional } & &
\end{array}
$$

Table 2 shows that, in terms of productive tillers, there was significant interaction between varieties and irrigation treatment. Both the variety and irrigation treatments showed no significant difference in growth. The irrigation treatment 
using SRI on IR 64 variety showed significantly higher influence than on Mekongga and Inpari Sidenuk using SRI, and Inpari Sidenuk using conventional irrigation method. IR 64 using SRI produced 15.67 productive tillers because intermittent irrigation will create an aerobic condition, increasing the roles of anaerobic organisms in rice roots. According to [14], providing enough nitrogen will increase the number of productive straws since nitrogen plays an important role as a constituent of protein for plants to increase the number of panicles per plant.

Table 2. Average productive tillers of rice plants aged 12 weeks

\begin{tabular}{ccccccc}
\hline Treat-ment & IR64 & Mekongga & $\begin{array}{c}\text { Cihe- } \\
\text { rang }\end{array}$ & $\begin{array}{c}\text { Inpari } \\
\text { Si } \\
\text { denuk }\end{array}$ & $\begin{array}{c}\text { HIPA } \\
\mathbf{1 8}\end{array}$ & Mean \\
\hline SRI & $15.67 \mathrm{a}$ & $11.33 \mathrm{c}$ & $14.89 \mathrm{abc}$ & $12.00 \mathrm{bc}$ & $\begin{array}{c}13.78 \\
\mathrm{abc}\end{array}$ & 13.53 \\
$\begin{array}{c}\text { Conventiona } \\
1\end{array}$ & $\begin{array}{c}12.55 \\
\mathrm{abc}\end{array}$ & $15.44 \mathrm{abc}$ & $12.34 \mathrm{abc}$ & $11.89 \mathrm{bc}$ & $\begin{array}{c}13.44 \\
\mathrm{abc}\end{array}$ & 13.13 \\
\hline Mean & 14.11 & 13.39 & 13.61 & 11.95 & 13.61 & $(+)$ \\
\hline
\end{tabular}

Numbers followed by the same letter in a column show there is no significant difference based on the F test and DMRT at $\alpha=5 \%$

$(+)=$ There is interaction between varieties and irrigation treatment

Figure 4 shows that the variety treatment with irrigation could increase the growth of productive tillers from week 8 to week 12 . In the $8^{\text {th }}$ and $12^{\text {th }}$ week, IR 64 variety had the highest growth of productive tillers, while in the $12^{\text {th }}$ week, IR-64 given SRI treatment showed the highest growth of productive tillers. SRI could provide a conducive condition for the growth of tillers because of the absence of flooded field during the vegetative stage [12].

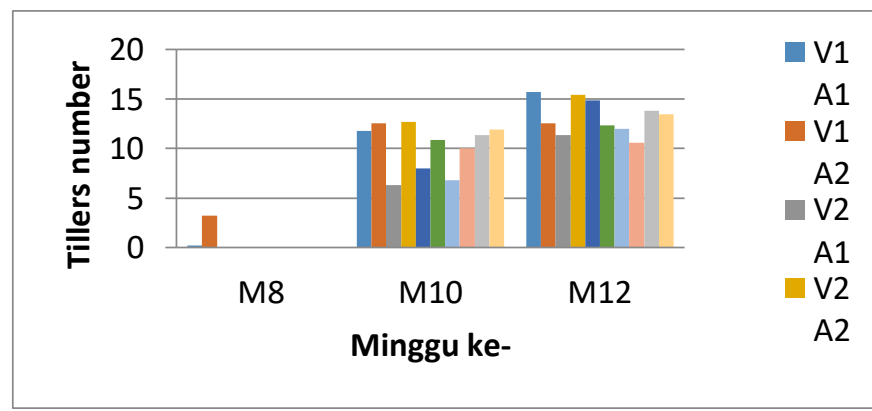

Figure 4. Histogram of Productive Tiller Growth

$\mathrm{V} 1=\mathrm{IR}-64$

$\mathrm{V} 2=$ Mekongga

$\mathrm{V} 3=$ Ciherang

A2 $=$ Conventional

In terms of the root of rice, Table 3 shows that there was no significant interaction between varieties and irrigation. Both the variety and irrigation treatments showed significantly different growth. HIPA 18 variety had significantly longer root than $64 \mathrm{IR}$, Ciherang and Mekongga.

The root of Inpari Sidenuk was significantly longer than those of other varieties. Plants growing in a field with intermittent irrigation are believed to have more and longer roots compared to those growing in a continuously flooded field. SRI irrigation method produced root length of 38.48 $\mathrm{cm}$, much longer than conventional method i.e. $35.29 \mathrm{~cm}$.
This suggests that in a flooded field, the soil becomes hypoxic (oxygen deficiency) for roots, making it not ideal for the growth of rice plants. This way, the root length will decrease.

Table 3. Average root length and leaf area of rice plants aged 12 weeks

\begin{tabular}{lcc}
\hline \multicolumn{1}{c}{ Treatment } & Root Length $(\mathbf{c m})$ & $\underline{\text { Leaf Area }\left(\mathbf{c m}^{2}\right)}$ \\
\hline IR-64 & $34.05 \mathrm{q}$ & $\underline{\underline{529.17 \mathrm{p}}}$ \\
Mekongga & $36.24 \mathrm{q}$ & $\underline{\underline{589.67 \mathrm{p}}}$ \\
Ciherang & $37.00 \mathrm{q}$ & $\underline{\underline{645.17 \mathrm{p}}}$ \\
Inpari Sidenuk & $35.57 \mathrm{q}$ & $\underline{\underline{535.33 \mathrm{p}}}$ \\
HIPA 18 & $41.54 \mathrm{p}$ & $\underline{\underline{654.00 \mathrm{p}}}$ \\
\hline SRI & $38.48 \mathrm{a}$ & $\underline{\underline{615.67 \mathrm{a}}}$ \\
Conventional & $35.28 \mathrm{~b}$ & $\underline{\underline{565.67 \mathrm{a}}}$ \\
\hline Interaction & $(-)$ & $(-)$ \\
\hline Treatment & Root length $(\mathrm{cm})$ & Leaf area $\left(\mathrm{cm}^{2}\right)$ \\
\hline Numbers followed by the same letter in a column show there is no significant difference based on the & F test and DMRT at $\alpha=5 \%$.
\end{tabular}

Figure 5 (a) shows that the variety treatment generated a relatively similar root length in week 4 , while in the $8^{\text {th }}$ week, Ciherang had the longest root, while in the $12^{\text {th }}$ week, the longest root was found on HIPA18. Figure 7 (b) shows that the irrigation treatment in the $4^{\text {th }}$ week generated a relatively similar root growth, but in week 8 conventional treatment generated longer roots, while in the $12^{\text {th }}$ week SRI generated longer roots. This shows that using SRI method will result in better growth in terms of root length. By using SRI method, the growth of roots is better when planting only 1-2 seedlings per polibag.

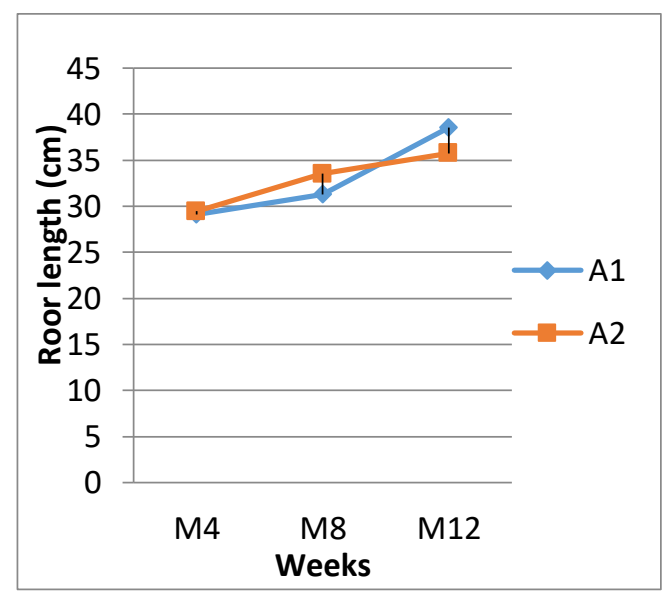

Figure 5 (a). Root Length of Rice Plants

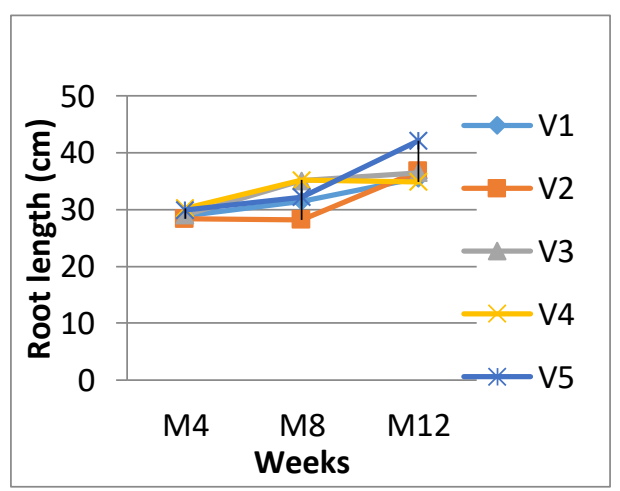

Figure 5 (b). Root Length of Rice Plants 
The results of leaf area in Table 3 showed that there was no significant interaction between variety dan irrigation. Both the variety and irrigation treatments showed no significantly different growth. Basically, the abilities of each plant leaf to produce the products of photosynthesis are different, requiring additional nutrients to produce primary metabolites. The energy generated depends on the ratio of external and internal of leaves [08].

Figure 6 (a) shows that the variety treatment in the $4^{\text {th }}$ and $8^{\text {th }}$ weeks showed that the broadest leaf areas were found on HIPA 18, affected by genetic and environmental factors of the fields where the plants grew. Figure 8 (b) shows that the irrigation treatment with SRI method showed the broadest leaf area in week 4 and 8 . This is in accordance with a statement by [10] that if there is excessive water, the excess water becomes inefficient or not beneficial for the growth of plants.

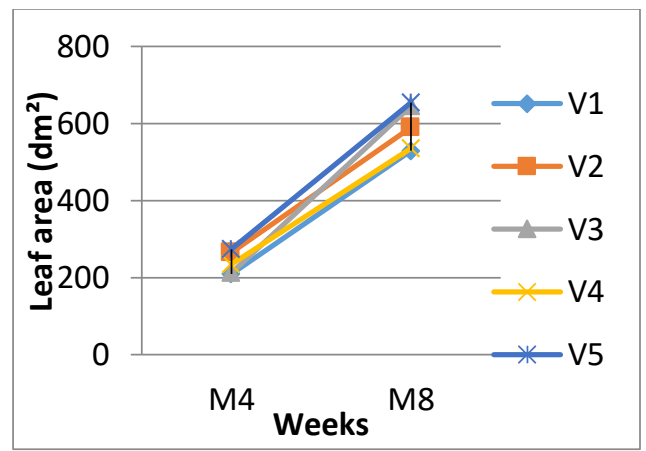

Figure 6 (a). Leaf Area of Rice Plant

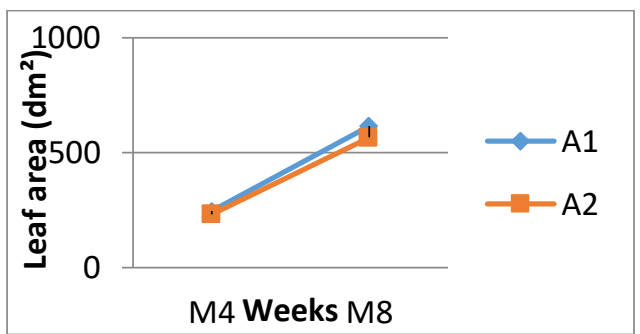

Figure 6 (b). Leaf Area of Rice Plant

$$
\begin{array}{ll}
\text { V1 }=\text { IR-64 } & \text { V4 }=\text { Inpari Sidenuk } \\
\text { V2 }=\text { Mekongga } & \text { V5 }=\text { HIPA 18 } \\
\text { V3 }=\text { Ciherang } & \text { A1 }=\text { SRI } \\
\text { A2 }=\text { Conventional } &
\end{array}
$$

In terms of the rice panicle length, there was no significant interaction between varieties and irrigation. The variety treatment showed significantly different growth, whereas the irrigation treatment showed no significant difference. The treatment on HIPA 18 variety resulted in longer panicles, i.e. 28.04than Inpari Sidenuk, However, the panicle length of Inpari Sidenuk i.e. 25.51 was longer than those of Ciherang and Mekongga. Finally, those of Ciherang and Mekongga had longer panicles than those of IR 64. On the other hand, the irrigation treatment showed relatively the same influence, meaning that using SRI irrigation method was sufficient to boost the growth of panicles. This is in accordance with a research that panicle length and number of grains per panicle are not affected by irrigation system, but each variety has different panicle lengths and different numbers of grains per panicle due to genetic factors.

Table 4. Average Panicle Length of Rice Plants

\begin{tabular}{lcccccc}
\hline $\begin{array}{l}\text { Treat- } \\
\text { ment }\end{array}$ & IR-64 & Mekongga & $\begin{array}{l}\text { Cihe } \\
\text { rang }\end{array}$ & $\begin{array}{l}\text { Inpari } \\
\text { Side- } \\
\text { nuk }\end{array}$ & \multicolumn{2}{l}{$\begin{array}{l}\text { HIPA- } \\
\mathbf{1 8}\end{array}$} \\
\hline SRI & 22.90 & 24.20 & 24.37 & 25.42 & 28.10 & $24.99 \mathrm{a}$ \\
\hline $\begin{array}{l}\text { Conventi } \\
\text { onal }\end{array}$ & 22.57 & 23.85 & 24.35 & 25.59 & 27.98 & $24.87 \mathrm{a}$ \\
\hline & 22.73 & 24.03 & $\begin{array}{l}24.36 \\
\mathrm{r}\end{array}$ & $\begin{array}{l}25.51 \\
\mathrm{q}\end{array}$ & $\begin{array}{l}28.04 \\
\mathrm{p}\end{array}$ \\
\hline $\begin{array}{r}\text { Numbers followed by the same letter in a column show there is no significant difference based on the } \\
\text { F test and DMRT at } \alpha \text { level }=5 \% . \\
(-)=\text { There is no significant interaction }\end{array}$
\end{tabular}

\section{B. Physiology of Rice Plant}

Table 5 shows the Harvest Index, Net Assimilation Rate

\begin{tabular}{|c|c|c|c|c|}
\hline Treatment & $\begin{array}{c}\text { Harvest } \\
\text { Index }\end{array}$ & $\begin{array}{c}\text { NAR } \\
\text { (g/cm2/ } \\
\text { week) }\end{array}$ & $\begin{array}{c}\text { CGR } \\
\text { (g/cm2/ } \\
\text { week) }\end{array}$ & $\begin{array}{c}\text { SLW } \\
(\mathrm{g} / \mathrm{cm} 2 / \\
\text { week) }\end{array}$ \\
\hline IR-64 & $0.9717 p$ & $0.0100 \mathrm{p}$ & $0.0069 p$ & $0.0079 p$ \\
\hline Mekongga & $0.9417 \mathrm{pq}$ & $0.0082 q$ & $0.0064 p$ & $0.0081 \mathrm{p}$ \\
\hline Ciherang & $0.9284 q$ & $0.0120 \mathrm{p}$ & $0.0099 p$ & $0.0076 \mathrm{p}$ \\
\hline $\begin{array}{l}\text { Inpari } \\
\text { Sidenuk }\end{array}$ & $0.7850 \mathrm{r}$ & $0.0120 \mathrm{p}$ & $0.0085 p$ & $0.0083 \mathrm{p}$ \\
\hline HIPA 18 & $0.9267 \mathrm{q}$ & $0.0097 p$ & $0.0085 p$ & $0.0076 \mathrm{p}$ \\
\hline SRI & $0.9067 \mathrm{a}$ & $0.0110 \mathrm{a}$ & $0.0085 a$ & $0.0077 \mathrm{a}$ \\
\hline Conventional & $0.9147 \mathrm{a}$ & $0.0100 \mathrm{a}$ & $0.0076 a$ & $0.0081 \mathrm{a}$ \\
\hline Interaction & $(-)$ & $(-)$ & $(-)$ & \\
\hline
\end{tabular}
(NAR), Crop Growth Rate (CGR), and Specific Leaf Weight (SLW) of rice plants. These variables showed that there were no significant interactions between rice varieties and irrigation.

Table 5. Mean of Harvest Index, NAR, CGR, and SLW of Rice Plants

In terms of the variety treatment, Harvest Index was significantly different, whereas in terms of the irrigation treatment, the same variable showed no significant difference. The Harvest Index of IR- 64 was significantly higher than those of Ciherang and HIPA 18, while the Harvest Index of Ciherang and HIPA-18 was significantly higher than that of Inpari Sidenuk. $80 \%$ of the panicle weight of IR 64 is in the form of filled grain [13].

NAR was significantly different, whereas in terms of the irrigation treatment, the same variable showed no significant difference. NAR of Mekongga was significantly higher than those of IR-64, Ciherang, Inpari Sidenuk, and HIPA 18.

CGR and SLW were not significantly different. Both the variety and irrigation treatments showed no significant differences. This indicates that all varieties had the ability to produce dry matters on the dry weights of the assimilation results beginning with the same amount. While the water needs to produce results of the assimilation of the dry ingredients on the dry weight of the beginning is enough. This shows that the treatments on some varieties had the ability to produce the same quantity of dry matters as the result of assimilation in each unit of land area. In addition, the water 
needed to produce the same quantity of dry matters as the result of assimilation in every unit of land area was sufficient. The treatment on some varieties generated the same leaf weights and the same leaf areas, allowing IR 64, Ciherang, Mekongga, Inpari Sidenuk and HIPA-18 to have the same leaf thickness.

\section{Components of Yields of Rice Plant}

Table 6 shows the average weight of grain per plant, the percentage of unfilled grain, and the weight of 100 grains. The results of the analysis on these variables indicated that there was no significant interaction between varieties and irrigation, meaning that there was no interaction between the varieties and irrigation treatments on these variables.

Table 6 . Average grain weight per plant, \% unfilled grain, and grain weight of 100 grains of paddy

\begin{tabular}{lll}
\hline \multicolumn{1}{c}{ Treatments } & \multicolumn{1}{c}{$\begin{array}{c}\text { Grain Weight Per } \\
\text { Plant (G) }\end{array}$} & \multicolumn{1}{c}{$\begin{array}{c}\text { \% Unfilled } \\
\text { Grain (\%) }\end{array}$} \\
\hline IR-64 & $23.468 \mathrm{pq}$ & $11.46 \mathrm{r}$ \\
Mekongga & $24.923 \mathrm{p}$ & $24.98 \mathrm{q}$ \\
Ciherang & $25.020 \mathrm{p}$ & $19.44 \mathrm{q}$ \\
Inpari Sidenuk & $19.328 \mathrm{q}$ & $45.59 \mathrm{p}$ \\
HIPA 18 & $25.968 \mathrm{p}$ & $24.98 \mathrm{q}$ \\
\hline SRI & $23.577 \mathrm{a}$ & $24.48 \mathrm{a}$ \\
Conventional & $23.907 \mathrm{a}$ & $24.39 \mathrm{a}$ \\
\hline Interaction & $(-)$ & $(-)$ \\
\hline \multicolumn{1}{c}{ Numbers followed by the same letter in a column show there is no significant } \\
\multicolumn{2}{r}{ difference based on the F test and DMRT at $\alpha=5 \%}$. \\
$\quad(-)=$ There is no significant interaction
\end{tabular}

The variety treatment showed different grain weights per plant, but the irrigation treatments showed no significant difference. HIPA-18, Ciherang and Mekongga showed higher grain weight per plant than Inpari Sidenuk i.e. 19.33 g. This was due to several factors including the grain filling process, assimilates produced by the plant organs that serve as source, translocation system from source to sink, and accumulation of assimilates in sink. The process of grain filling is a balance of these three [14]. The difference between rice plants producing high yields and those producing low yields is found in their abilities to accumulate dry maters before heading and translocations of assimilates during grain filling [15].

The variety treatment showed significantly different results, while the irrigation treatment showed no significant difference. IR 64 variety had lower percentage of unfilled grains, i.e. $11.46 \%$ than HIPA-18, Ciherang and Mekongga. Meanwhile, HIPA 18, Ciherang and Mekongga showed a lower percentage of unfilled grain than Inpari Sidenuk. This is in line with a statement by [18] that the age of seedlings also has similar trend: the older the seedlings when transplanted, the higher the percentage of unfilled grains.

\section{CONCLUSION}

The results show that variety treatments affect the physiology, growth, and yields of rice plants. SRI and conventional method affect the growth, but not the physiology and yields of rice plants. On productive tillers, there is an interaction between varieties and irrigation.

\section{REFERENCES}

[1] BPS, "Badan Pusat Statistika," 2014. [Online]. Available: https://www.bps.go.id/index.php. [Accessed 17 December 2016].

[2] S. Armansyah and R. Anggraini, Pengaruh periode pengenangan air terhadap pembentukan jumlah anakan pada tanaman padi (Oryza Satifa) dengan metode SRI (The System of Rice Intensification), Padang: Andalas University, 2009.

[3] S. Sato and U. N, Raising Factor Productivity in Irrigated Rice Production: Opportunities with The System of Rice Intensification, DISIMP, 2006.

[4] D. Berkelaar, "System of Rice Intensification (System of Rice Intensification)," $2008 . \quad$ [Online]. Available: http://elsppat.or.id/download/file/SRI echo\% 20note .htm.. [Accessed 9 May 2015]

[5] N. Uphoff, R. S and J. R. Darsana, What is the System of Rice Intensification, Cornell University, 2002.

[6] R. P. Cantrell, Foreword. In Redesigning the Rice Photosynthesis to Increase Yield, Los Banos: IRRI, 2000.

[7] BBPADI, "Balai Besar Penelitian Tanaman Padi," 2015. [Online]. Available: http://bbpadi.litbang. pertanian.go.id/ . [Accessed 1 June 2016].

[8] B. Abdullah, S. Tjokrowidjojo and Sularjo, "Tatus, Perkembangan, dan Prospek Pembentukan Padi Tipe Baru di Indonesia," Proceedings of The V Symposium On Food Crops - Technological Innovation Food Crops. Centre for research and development of food crops, Agricultural Research and Development Agency., vol. 2, pp. 269-287, 2008.

[9] F. B. Sallisbury and C. W. Ross, Plant Physiologi, California: Wadsworth Publishing Company Belmont, 1995.

[10] Kurnia, F. A. Undang, A. Abdurachman and D. Ai, Sifat Fisik Tanah dan Metode Analisisnya. Bogor, Balai Besar Penelitian dan Pengembangan Sumber Daya Lahan Pertanian, 2006.

[11] M. G. Hale and D. M. Orcutt, The Physiology of Plants Under Stress, New York: John Willey and Sons, 1987.

[12] W. Wangiayana, Z. Laiwan and Sanisah, Pertumbuhan dan Hasil Tanaman Padi Var. Ciherang dengan Teknik Budidaya "SRI (System of Rice Intensification)" pada Berbagai Umur dan Jumlah Bibit Per Lubang Tanam., Universitas Mataram, 2009.

[13] A. Makarin, "Optimization of Components Of the Results of the Rice Varieties," Balai Besar Penelitian Padi, 2005.

[14] K. Sumardi, M. Kasim, A. Sharif and N. End, "The Response of Rice Cultivated in Aerobic Technique and the Granting of Organic Materials," Agnosia Deed Journal, vol. 10, no. 1, pp. 65-71, 2007.

[15] M. N. H. Miah, T. Yoshida, Y. Yamamoto and Y. Director, "Characteristics of Dry Matter Production and Partitioning of Dry Matter in High Yielding Spring Dwarf Indica and Japonica Indica Hybrid Rice Varieties 1," JPN J Crop Sci, vol. 65, pp. 672-685, 1996.

[16] [Online]. Available: http://bbpadi.litbang. pertanian.go.id/. 